\title{
Education in the Context of Digitalization and Culture: Evolution of the Teacher's Role, Pre-pandemic Overview
}

\author{
Olga Kalimullina \\ The Bonch-Bruevich St. Petersburg State University of Telecommunications, Russian Federation
}

\author{
Bulent Tarman ${ }^{1}$ \\ Independent Researcher, Turkey \\ Irina Stepanova \\ ITMO University, St. Petersburg, Russian Federation
}

\begin{abstract}
This study was conducted before the outbreak of the pandemic and now the results seem clear. The intensive forced use of distance technologies in the educational process has changed the approach to education forever. What exactly has changed? this is already a topic for new research. We suggest going back a little and see how the role of the teacher changed as the use of digital technologies intensified before the pandemic. This article analyzes the studies devoted to teachers' experiences in interacting with digital environments, and reviews digital learning systems, environments, and tools. The study found that there are many opportunities, applications, and automated digital environments in the world, but none of them can, to a greater or lesser extent, do without a supervisor, or a teacher. In addition, the paper found that, despite the diversity of digital learning tools, that issues existed related to using such tools by teachers due to the lack of adequate digital competence or even because some teachers tend to have a negative attitude towards this new concept of education. Therefore, sufficient conditions and opportunities should be created for teachers to obtain the required digital competence and to explore the culture of digital technology in education and learning environments to succeed in the subsequent integration of digital technology into the field of education.
\end{abstract}

Keywords: digital competence, digital education, e-learning, evolution of the Teacher's Role, innovation, MOOC, teaching.

This study was conducted before the pandemic. And in modern conditions, it is especially interesting to analyze how the teacher's role has changed in the new digital environment, how this role was perceived before the pandemic. In recent years, before the pandemic, significant investments have been made into the digitalization of education. Universities faced the issue of redefining the teacher's role within the learning process long before the outbreak of the pandemic (Noble, 1998; Ladyzhets and Neborskij, 2015). The digitalization of the learning process also leads to its globalization, which affects the evolution of teaching techniques, progress assessment, and interaction between teachers and students.

\footnotetext{
${ }^{1}$ Correspondent Author E-Mail: btarman@gmail.com
} 
The main objective of the study was to determine the interactions of the following paired groups: teacher-digital tool and student-digital tool, the influence of teachers on the learning process when using new learning technologies, as well as to analyze the influence of digital technologies on teachers and students. The paper also describes digital learning technologies used and implemented worldwide and analyzes how digital technologies affect both pairs of the learning process.

The research has the following structure. The method section describes the stages of conducted systematic literature review, inclusion and exclusion criteria. The literature review considers the discussion on the interaction between teachers and students, teacher-digital tool and student-digital tool, the influence of teachers on the learning process when using new learning technologies. Findings session summarize the obtained results. Discussion session answer the question if the obtained results are relevant in the pandemic while the learning process extremely changed and the university community faces new reality.

Theoretical research on the problem of understanding students' learning practices, interaction of the pair student-digital tool has already been considered in works of Viberg \& Grönlund (2017), Kupriyanovskij et al. (2016), Watson et al. (2015) Korableva et al. (2019), etc. Teaching in a digital age, problem of interaction of teacher and student in the context of digital environment were considered in the works of Bates \& Bates (2015), Bruce \& Chiu (2015), etc.

\section{Literature Review}

Development and introduction of new technology and information systems inevitably leads to the transformation in global economy. A review of the book Rise of the Robots by Martin Ford presents pessimistic and optimistic options for further development of the humankind due to the active usage of information technology (Virgillito, 2017). Many analytical articles have been published over the past few years also predict changes in the economic and social environments in the context of increasing automation. This confirms that the attitude of society to automation and its possible prospects has changed.

Smater and Zieliński (2015), in support of the reflections of entrepreneur Martin Ford, the Polish researcher, said that at the moment Europe aims to reindustrialize the economic society by 2020. The reindustrialization, as referred to in the article, will be conducted to increase automation in many new companies, as well as in small and medium-sized businesses (which account for 99\% of the total European businesses) to the level at which costs related to common manual labor will cease to exist.

Kaivo-oja and Roth (2015) conducted a large study and foresaw key trends in automation and robotization. They identified three main directions of future development in information technology: 1) information and communications technology, 2) digitalization and the widespread development and 3) the use of robots. According to the authors, such an increase in information flows is going to be long term, and society will turn into a "modern ubiquitous knowledge society." In such a society, human interaction will be minimal, while machine interaction (so-called "machine-to-machine communication"), as well as interaction between databases and computing devices will grow stronger.

Tsirel (2017) assumed that, in the near future, due to the development of automation and a reduction of manpower needs, society will be divided into several strata depending on people's ability to work intellectually and communicate. A similar article by Lukina et al. (2016) examined how the coming robotization would influence society. In this case, unlike Tsirel (2017), the assumption was made that robots may replace humans even in the social sector. 
Upadhyay's (2015) article "Can Capitalism Survive High Degree of Automation?” studied the issue of automation from a slightly different angle. Capitalism is impossible without the consumer; therefore, Upadhyay wonders whether businesses and small enterprises (when applying automatic devices and replacing manual labor) would be able to survive in the future when people will be unable to afford the goods due to the very automation used by businesses to produce the goods. The answer to this question lies in the fact that, according to the author, despite the significant workplace reduction in many fields due to automation, various new occupations will occur in which the use of automated devices will be impossible.

Thus, most researchers agree that technology will replace manual labor and working-age people will improve or change their skills finding jobs at enterprises and production companies that operate in uncommon fields, most likely associated more with social interactions (Woofter, 2019).

This was partially proved by the paper of Garduno-Aparicio et al. (2018) that presented a robot prototype for an undergraduate laboratory program designed to fulfill the criteria laid out by ABET. The main objective of the program is for students to learn some basic concepts of embedded systems and robotics, and apply them in practice.

As educational technology indicates an ever-increasing automation of educational activity, some have predicted that teachers will be replaced by robots. However, in the article by Coelho (2018), these statements were considered as provocations and make us doubt our understanding of educational practice. The article is an interesting discussion on the topic of automation, trying to understand the meaning of this process and why so many hopes are associated with the automation of education.

Education will not disappear from the human society; therefore, automation will affect (and it already does) education, too. The parties involved in the learning process may be divided into two social groups influenced in varying degrees by new technologies and tools. On one hand, students will be more capable of learning thanks to multimedia technology, gamification, and the rapid expansion of distance education (e-learning), etc. And, on the other hand, the introduction of new technologies involves new opportunities and challenges at the same time of teachers.

In the paper "Gamification in education: a systematic mapping study" Dicheva et al. (2015) examined the learning gamification phenomenon. As the researchers highlight, many students believe that education is boring, monotonous, and even tiring, but game elements could help them get motivated enough to learn. The authors found that, despite the diversity of game-based learning approaches, these approaches lack empirical research; indeed, the issue of impact and quality of knowledge obtained because of gamified training has not been fully resolved yet.

Viberg and Grönlund's (2017) study, "Understanding students' learning practices: challenges for design and integration of mobile technology into distance education", was dedicated to the importance of designing mobile applications for distance learning (e-learning). The authors started to analyze this issue with a study of how students use technologies for learning, and what technologies they use. It turns out that, even though students frequently use mobile applications on their smartphones or tablets in everyday life, most find it easier to use both mobile and desktop software versions when it comes to learning. The paper also notes that everyone uses interactive learning materials differently: many people prefer to learn something during breaks (for example, when on public transport), and a group learning mode or project-based learning mode makes it difficult for them to master a course (Brigas, 2019; Fernández et al., 2019).

Aleksandrovna et al.'s (2017) publication "Digital transformation as the factor of the generation dynamics in the information society" provided an extensive empirical sociological survey on how the society transforms in terms of information), which it is to some extent confirmed 
by the analytical reasoning of the above-mentioned works. The authors conducted a large-scale questioning of the population (1,500 people), conducted a series of in-depth interviews with several generations of the same family (20 families), and collected 100 student essays. The focus group comprised active Internet users; their profiles in social media were thoroughly analyzed. The results showed that different generations faced a significant gap in the approach and the practice of using information technology. The developing digital environment creates fundamentally new conditions for social identification and self-expression.

With respect to the topic of learning, students aged up to 25 years perceive the digitalization of education in a natural way, as most of them were born in the period of rapid development of gadgets (such conclusion indirectly confirms the theory of generations). Notably, trends in the use of technologies are in some way correlated with data related to the theory of generations (Borges et al., 2010; Lai \& Hong, 2015; Loh \& Ang, 2020; Papadakis, 2018).

The analysis of a teacher's role under full digitalization of learning is presented below. Teachers represent another social layer involved in the learning process and are exposed to the impacts of automation. Claims by different generations with respect to the learning process affect teachers in transforming learning environment. As for teachers, the emergence of new technologies is fraught with the need for continuous advanced professional training. This forces them to adjust themselves and rebuild their methodologies and approaches to the new learning paradigms (Bates \& Bates, 2015).

In view of the dynamic introduction of digital educational environments and e-learning, as already mentioned, the issue of the role of and need for a teacher within the learning process is raised. This article provides the analysis of digital educational technologies, used and implemented in the world, and analysis of how digital technologies affect both parties of the learning process.

Studies have addressed new development programs tasks of the digitization of economy (Namiot et al., 2017), and laws and projects on how to use digital data and technologies (Kupriyanovskij et al., 2016). However, few articles have dealt with the direct reflections of the impacts of such programs in learning by students and teachers with various majors.

Several researchers believe that new digital technologies will significantly change the professional practices of teachers and their areas of responsibility in the learning process, but the process of education for teachers should not be changed significantly to adjust to such changes (Fenwick \& Edwards, 2016; Papadakis \& Kalogiannakis, 2017). A teacher is a key figure within the traditional concept of education. In contrast, some studies provide a rationale and positive experience of such changes (Bruce \& Chiu, 2015; Instefjord, 2015; Nielsen et al., 2015; Tømte et al., 2015).

Bruce and Chiu (2015) suggested that, to assign digital competence and promote the use of digital technologies within the framework of the professional didactic competency of teachers, it is necessary to integrate technology as a pedagogical tool for teachers more effectively and include it into teacher training programs. However, a major problem with integrating digital competence in educational institutions for teachers exists because by the time of approval and implementation of the program, its content may be out of date. Therefore, the focus should not only be on mastering tools, but also on obtaining digital competence that covers an awareness of the teacher of how exactly the technology may be used critically and reflectively in the formation of new knowledge.

\section{Methods}

The systematic literature review was chosen as the main research method. Because the introduction of information technologies into the educational environment occurs quite quickly, 
the issue of the influence of educational information technologies on the role of the teacher has been focus of international research since decades. The review of existing publications and open data on educational tools is the only possible way to structure and summarize all the information available at the moment within the framework of the indicated problem.

During this study, a structured literature review is conducted. The expanded version of the Scopus database, the world's largest universal abstract database, is used for this purpose. The search for such word groupings as "automation", "education", "technology" is performed in the headings of the articles. The search is limited to the documents published during the 2015-2019 full years. The sources and a basic set of keywords are expected to provide a good sample of literature. The completeness of the results cannot be assured at this stage, taking into account only the headings and a limited set of keywords. However, this is considered sufficient for this stage of the study. In the course of the study, a headline is studied first and a decision is made on the applicability of the article, then, if the article is the subject to the header check, the keywords and the abstract are studied. The exclusion criteria on this stage: the article doesn't contain any discussion on the interaction between teachers and students, teacher-digital tool and student-digital tool, the influence of teachers on the learning process when using new learning technologies. If the article passes the second check, the full text of the article was analyzed. The search for the articles by the keywords resulted in the identification of 939 works: 267 for 2019, 214 for 2018, 171 for 2017, 156 for 2016, 131 for 2015. The study of the headlines limited the articles to 36 for 2019, 56 in 2018, 45 in 2017, 46 in 2016, 31 in 2015. After that, we set the open access inclusion criteria to be able to read the entire article. Thus, 28 articles were selected for the analysis.

\section{Findings}

To meet the needs of the modern economy and labor market, education must go beyond tradition. A new Education 3.0 concept entirely focuses on the student. It implies a personal trajectory for every student and draws attention to new skills and competencies being obtained by students rather than on simple marks, as evidence that any particular subject has been mastered (Govindasamy \& Kwe, 2020; Kupriyanovskij et al., 2016; Watson et al., 2015). To implement the Education 3.0 concept successfully, using digital tools within the framework of the learning process becomes not a whim, but a necessity.

Digital environment used in the learning process is presented below, some examples of automated digital technologies that are applied in different countries are provided.

\section{a) Modular Digital Learning Environments}

Some educational institutions and companies create their own integrated digital modular learning environments. One of these is the PIES (personalized integrated educational system). The system is currently being improved (Kupriyanovskij et al., 2016; Watson et al., 2015). It will provide students, teachers, parents, and other interested parties with full functionality. When using this system, the role of the teacher in the personality oriented paradigm of Education 3.0 will move to that of intermediator or coach. The teacher will choose and design learning tools for students in modular systems. PIES is expected to be a built-in modular technology, which will be compatible with all aspects of the learning process. The product has an open source code, which may increase the rate of distribution and implementation of technology for the prospective of further integration in educational institutions. In the future, distant support is expected to be provided to the users for lifelong learning. 
Sometimes, some semblance of modular systems is applied during the programming world championships (ACM ICPC). Researchers share their experience in dealing with automated programs in an article titled "The Role of Automation in Undergraduate Computer Science Education" (Wilcox, 2015). They talk about how an automated system can be applied for the evaluation of the program code during examinations and programming competitions. The article analyzes the influence of a built-in automated system on the learning process. The researchers found that a carefully designed controlled system might not only solve the problem of training and human resources, but also improve student performance. It was found that automated tests increased student interest in a subject, particularly due to opportunity to evaluate their own activities and those of their colleagues. However, some shortcomings were found in the system like a lack of optimal flexibility when checking the program code of the students. This fact may call into question the possibility of verifying the code only by an automated system.

NGDLE (next generation digital learning environment) may be another example of a modular digital learning tool (Brown et al., 2015). The technology has been developed by Bill and Melinda Gates Foundation, which studies the emerging gaps between current learning management tools and the digital learning environment. They also define the concept based on the modular approach, which is, according to the developers, similar to Lego. The main criteria for this environment include: interoperability between users, personification, automated analytics, consulting and educational assessment, cooperation with third-party agents and universal design. The environment allows the creation of conditions for training, considering the individual needs and traits of students. However, NGDLE also needs a teacher who can build a personal trajectory, taking into account the trainee's characteristics, as well as to monitor the progress of his students.

\section{b) Massive Open Online Courses (MOOC) and Distance Education}

MOOC (massive open online courses) is a state-of-the-art educational project. MOOC platforms can simultaneously be used as both a tool and digital environment. At the moment, more than 48 million students are signed up on most popular worldwide MOOC platforms (Coursera, edX, XeuetangX, FutureLearn and Udacity) (Kupriyanovskij et al., 2016). Notable, is that the reduction in number of free courses and exclusive premium content being added to courses has been the underlying trend on these worldwide platforms in 2016 and 2017.

Research of requirements to online courses has emerged in recent years. At the same time, as many researchers have noted (Freitas et al., 2015; Ng'ambi \& Bozalek, 2015; Ohlin, 2019) that. despite the evident advantages of distance e-learning for higher education institutions (Kaplan \& Haenlein, 2016) as well as the objective usefulness of MOOC for people with physical conditions and the usability of online lectures as an alternative to traditional textbooks, distance education is not perfect.

One main problem of MOOC is the low degree of course completion - only approximately $10 \%$ of students complete the online training. In addition, only a few empirical studies have been devoted to the actual efficiency of MOOC. Thus, remains unclear for which subjects online courses are an effective form of training and for which ones this model might be inappropriate. The limiting factor for the development of widespread use of MOOC is absence of a teacher guiding the learning, and, as a result, a lack of feedback required for effective learning (Uribe \& Vaughan, 2017). The lack of motivating factor in online courses leads to failure to complete a course.

The lack of flexibility may be considered the downside of MOOC. Despite small technical differences between the platform structure and platform interfaces, the format of all currently known MOOC platforms involves the use of video lectures and multiple-choice questions test with 
open-ended and closed-ended questions. There are not enough opportunities and functionality to integrate additional tools, for example, gamification items, into the learning process, which would increase user involvement. MOOC is completely embedded into the concept of lifelong learning, as a platform for further education for adults. It is, however, unclear whether MOOC can lead a student through all three stages of education: undergraduate, graduate, and postgraduate studies.

The low motivation of students and the low percentage of successful completion of courses entail the need for a teacher, tutor or coach to work together with the MOOC platforms. A possible solution to this problem for an organizing MOOC platform could become a paid subscription to the tutoring. Thus, MOOC would organically combine with online tutoring, which could increase the percentage of those completing the course.

\section{c) LMS and LCMS Systems}

LMS (learning management systems) are used to organize distance learning (Klassov \& Klassova, 2016), which are implemented through programs like LCMS (learning content management system). These are used for designing, managing, and delivering online training materials subject to providing joint user access. LMS create a single learning environment that is convenient for studying the theory, proactive practicing and getting feedback from a teacher. Such systems also provide an opportunity for teachers to create courses in the visual virtual environment. Due to the already quite long existence and development of such systems, there is an entire group (Poulova et al., 2015) of successful LMS, such as Adobe Captivate Prime, Moodle, and Claroline, among others. When using LMS systems the teacher's contribution to the learning process remains similar to that of traditional education, but the learning process itself is transferred to the digital environment.

Table 1 presents the main features of all educational environments in conjunction with the student and teacher. 
Table 1

Main Features of Educational Environments (Interaction of the Pairs Student-Digital Tool, Teacher-Digital Tool)

$\begin{array}{llllll}\begin{array}{l}\text { Educational } \\ \text { environments }\end{array} & \begin{array}{l}\text { The target } \\ \text { audience (users) }\end{array} & \begin{array}{l}\text { Public or } \\ \text { private }\end{array} & \begin{array}{l}\text { Opportunities and features for } \\ \text { users }\end{array} & \text { Teachers' role } & \text { Problems }\end{array}$

\section{environments

Modular digital
learning

environments

Students (also

teachers, parents)

in specific school

or in educational

institution, college
Private

Users have recording, scheduling,

instructing and assessment tools

monitor reporting on indicators of

students' individual competencies,

contain data on each student's

performance, required standards

and instructions for further

development of the student. As well

as individual training programs

modular technology automated

system, personalization, analytics,

consulting and educational

assessment.
A teacher as a classical

teacher

A teacher will choose

and design learning tools

for students. Teachers

create with modules a

personal educational

track, make exam tests

and oversee results.
Lack of optimal

flexibility for users.

Each module is

unaltered.
PIES, NGDLE,

etc.

\begin{tabular}{|c|c|c|c|c|c|c|}
\hline $\begin{array}{l}\text { Massive open } \\
\text { online courses } \\
\text { (MOOC) and } \\
\text { distance } \\
\text { education }\end{array}$ & Anyone & Public & $\begin{array}{l}\text { Students have access to various type } \\
\text { of video lectures and multiple- } \\
\text { choice questions test with open- } \\
\text { ended and closed-ended questions. } \\
\text { At the end of education in case of } \\
\text { reaching success during the course, } \\
\text { they get a certificate. }\end{array}$ & $\begin{array}{l}\text { Self-studying without } \\
\text { any teacher or coach }\end{array}$ & $\begin{array}{l}\text { Lack of student } \\
\text { motivation to continue } \\
\text { the course or low } \\
\text { student motivation; not } \\
\text { enough functionality to } \\
\text { integrate additional } \\
\text { tools }\end{array}$ & $\begin{array}{l}\text { Coursera, edX, } \\
\text { XeuetangX, } \\
\text { FutureLearn and } \\
\text { Udacity, etc. }\end{array}$ \\
\hline $\begin{array}{l}\text { LMS and } \\
\text { LCMS systems }\end{array}$ & $\begin{array}{l}\text { Students and } \\
\text { teachers in } \\
\text { chargeable online } \\
\text { courses or students } \\
\text { getting higher } \\
\text { education }\end{array}$ & Private & $\begin{array}{l}\text { Designing, managing, and } \\
\text { delivering online training materials } \\
\text { subject to providing joint user } \\
\text { access. LMS create a single learning } \\
\text { environment that is convenient for } \\
\text { studying the theory, proactive } \\
\text { practicing and getting a feedback } \\
\text { from the teacher. Such systems also } \\
\text { provide an opportunity for teachers } \\
\text { to create courses in the visual virtual } \\
\text { environment. }\end{array}$ & $\begin{array}{l}\text { A teacher as a } \\
\text { teacher/coach or tutor } \\
\text { Students choose a course } \\
\text { and teacher, or coach or } \\
\text { tutor facilitate them in } \\
\text { educational process. The } \\
\text { teacher can choose and } \\
\text { design learning tools } \\
\text { from the available } \\
\text { system tools for students. }\end{array}$ & $\begin{array}{l}\text { Lack of optimal } \\
\text { flexibility, } \\
\text { chargeability }\end{array}$ & $\begin{array}{l}\text { Netology LMS } \\
\text { System, Higher } \\
\text { School of } \\
\text { Economics } \\
\text { LMS (National } \\
\text { Research } \\
\text { University), } \\
\text { Adobe } \\
\text { Captivate } \\
\text { Prime, Moodle, } \\
\text { Claroline etc. }\end{array}$ \\
\hline
\end{tabular}




\section{Discussion and Conclusion}

The results of the analysis show that the figure of the teacher, even in connection with the use of digital instruments, is so far unchanged in the learning process. As shown in Table 1 and according to the studies referred to the findings section, the teacher's role is similar to the traditional form and, at the moment, the use of educational tools without involving the instructor in the process is still difficult. In the case of using mass online courses and distance education, the absence of a teacher leads to a low effectiveness of this teaching method.

The article was a meta-analysis of publications on the use and implementation of digital tools in the educational process. Problems were analyzed and identified by the teacher in the process of integration into the digital educational field, as well as new trends and trends in education that correlate with the characteristics of the theory of generations.

In view of the immutability of the role of the teacher as a tutor or curator of the educational process, even in non-traditional teaching models, to facilitate the integration of digital technologies into the educational process, developing teaching systems for teachers is necessary (Tadeu et al., 2019; Tarman, 2016, 2017). In addition, as the review of the literature has shown, training courses, trainings and seminars to increase the "digital literacy" of teachers will be in demand in the short term and require careful and detailed elaboration, as new technologies for teaching appear.

A promising continuation of this work would be the establishment of criteria for "digital competence" because the parameter itself is currently quite blurred (Gapsalamov et al., 2020; Rahmadi et al., 2020). The development of such criteria could solve the problem of identifying either the need for or lack of the need to acquire this competence for current teachers or in the future. In addition, possible follow-up work would establish a clear structure and classify approaches to learning, taking into account emerging new technologies because at the moment the distinction between MOOC courses, LMS systems and modular educational systems is relatively arbitrary (Novikov, 2020).

A review of publications prior to the pandemic led to these findings. The above conclusions remain relevant even now, when there has been an explosive growth in the use of distance technologies in education. The personality of the teacher remains a very important factor in the effective assimilation of knowledge.

As a result of the study, it can be concluded that the interaction "teacher-digital tool" and "student-digital tool" are successfully implemented, although are some issues, but both sides successfully overcome them. An excessive number of such tools interferes with the interaction between the teacher and the student, which is very important in the educational process. It was revealed that at the moment, digital educational environments cannot function successfully without the participation of the teacher, the role of the teacher may differ in different digital environments, but the most important is the personality of the teacher and its influence on the consciousness of the student.

At the same time, no clear definition of the term "digital competence" exists, which does not allow an assessment of the level of use of digital technologies in the learning process.

During the research, it was determined which features of information consumption are inherent in the generation that passes through the educational stages at the moment (according to the theory of generations). It was established which characteristics should be presented in the educational digital environment to increase the involvement of young people in education. Several examples of different types of non-traditional teaching methods (modular technologies, MOOC, LMS, etc.) were also examined, and the role the teacher (or tutor or mentor) has in them was revealed. 


\section{References}

Aleksandrovna, M. O., Iurievna, E. M., \& Olegovna, E. P. (2017). Digital transformation as the factor of the generation dynamics in the information society. QUID: Investigación, Ciencia y Tecnología, (1), 1624-1629.

Bates, A. T., \& Bates, A. W. (2015). Teaching in a digital age. https://opentextbc.ca/teachinginadigitalage/

Borges, N. J., Manuel, R. S., Elam, C. L., \& Jones, B. J. (2010). Differences in motives between Millennial and Generation X medical students. Medical Education, 44(6), 570-576.

Brigas, C. (2019). Modeling and simulation in an educational context: Teaching and learning sciences. Research in Social Sciences \& Technology, 4(2), 1-12. https://doi.org/10.46303/ressat.04.02.1

Brown, M., Dehoney, J., \& Millichap, N. (2015). The next generation digital learning environment. A Report on Research. https://library.educause.edu/ /media/files/library/2015/4/eli3035-pdf.pdf.

Bruce, D. L., \& Chiu, M. M. (2015). Composing with new technology: Teacher reflections on learning digital video. Journal of Teacher Education, 66(3), 272-287.

Coelho, H. (2018). The robot take-over: Reflections on the meaning of automated education. [O robô take-over: Reflexões sobre o significado do automação da educação; El "robot" takeover: Reflexiones sobre el significado de la automatización de laEducación] Education Policy Analysis Archives, 26. https://doi:10.14507/epaa.26.3863

Dicheva, D., Dichev, C., Agre, G., \& Angelova, G. (2015). Gamification in education: A systematic mapping study. Journal of Educational Technology \& Society, 18(3), 75-88.

Fenwick, T., \& Edwards, R. (2016). Exploring the impact of digital technologies on professional responsibilities and education. European Educational Research Journal, 15(1), 117-131.

Fernández, A., Camargo, C., \& Do Nascimento, M. S. (2019). Technologies and environmental education: A beneficial relationship. Research in Social Sciences and Technology, 4(2), 1330. https://doi.org/10.46303/ressat.04.02.2

Freitas, S. I., Morgan, J., \& Gibson, D. (2015). Will MOOCs transform learning and teaching in higher education? Engagement and course retention in online learning provision. British Journal of Educational Technology, 46(3), 455-471.

Gapsalamov, A. R., Bochkareva, T. N., Vasilev, V. L., Akhmetshin, E. M., \& Anisimova, T. I. (2020). Comparative analysis of education quality and the level of competitiveness of leader countries under digitalization conditions. Journal of Social Studies Education Research, 11(2), 133-150. https://jsser.org/index.php/jsser/article/view/1737/450

Garduno-Aparicio, M., Rodriguez-Resendiz, J., Macias-Bobadilla, G., \& Thenozhi, S. (2018). A multidisciplinary industrial robot approach for teaching mechatronics-related courses. IEEE Transactions on Education, 61(1), 55-62. https://doi:10.1109/TE.2017.2741446

Govindasamy, M. K., \& Kwe, N. M. (2020). Scaffolding problem solving in teaching and learning the DPACE Model-A design thinking approach. Research in Social Sciences \& Technology, 5(2), 93-112.

Instefjord, E. (2015). Appropriation of digital competence in teacher education. Nordic Journal of Digital Literacy, 10, 155-171.

Kaivo-oja, J., \& Roth, S. (2015). The technological future of work and robotics. EconStor Preprints 118693, ZBW - German National Library of Economics. https://www.econstor.eu/bitstream/10419/118693/1/Robotics.pdf 
Kaplan, A. M., \& Haenlein, M. (2016). Higher education and the digital revolution: About MOOCs, SPOCs, social media, and the Cookie Monster. Business Horizons, 59(4), 441450.

Klassov, A. B., \& Klassova, O. V. (2016). Ispol'zovanie sistemy distantsion-nogo obucheniya v uchebnom protsesse [Use of distance learning system in the educational process] Nauchnyj al'manah, 3(2), 165-169.

Korableva, O., Durand, T., Kalimullina, O., \& Stepanova, I. (2019). Usability testing of MOOC: Identifying user interface problems [Paper Presentation]. ICEIS 2019 - Proceedings of the 21st International Conference on Enterprise Information Systems, 2, 468-475.

Kupriyanovskij, V. P., Sinyagov, S. A., Namiot, D. E., Dobrynin, A. P., \& Hernyh, C., \& Yu, K.. (2016). Informatsionnye tekhnologii v sisteme universitetov, nauki i innovatsii v tsifrovoj ehkonomike na primere Velikobritanii [Information technologies in the system of universities, science and innovations in the digital economy on the example of Great Britain]. International Journal of Open Information Technologies, 4(4).

Ladyzhets, N. S., \& Neborskij, E. V. (2015). Universitetskij barometr: Mirovye tendentsii razvitiya universitetov i obrazovatel'noj sredy [University barometer: World trends in the development of universities and the educational environment]. Internet-zhurnal Naukovedenie, 7(2), 27.

Lai, K. W., \& Hong, K. S. (2015). Technology use and learning characteristics of students in higher education: Do generational differences exist? British Journal of Educational Technology, 46(4), 725-738.

Loh, R. C. Y., \& Ang, C. S. (2020). Unravelling cooperative learning in higher education. Research in Social Sciences \& Technology, 5(2), 22-39. https://doi.org/10.46303/ressat.05.02.2

Lukina, N. P., Slobodskaia, A. V., Zilberman, N. N. (2016). Social dimensions of labour robotization in post-industrial society: Issues and solutions. Man in India, 96(7), 23672380.

Namiot, D. E., Kupriyanovskij, V. P., Samorodov, A. V., Karasev, O. I., Zamolodchikov, D. G., \& Fedorova, N. O. (2017). Umnye goroda i obrazovanie v tsifrovoj ehkonomike [Smart cities and digital education]. International Journal of Open Information Technologies, 5(3).

Ng'ambi, D., \& Bozalek, V. (2015). Massive open online courses (MOOCs): Disrupting teaching and learning practices in higher education. British Journal of Educational Technology, 46(3), 451-454.

Nielsen, W., Miller, K. A., \& Hoban, G. (2015). Science teachers' response to the digital education revolution. Journal of Science Education \& Technology, 24(4), 417-431.

Noble, D. F. (1998). Digital diploma mills: The automation of higher education. Science as culture, $7(3), 355-368$.

Novikov, P. (2020). Impact of COVID-19 emergency transition to on-line learning onto the international students' perceptions of educational process at Russian university. Journal of Social Studies Education Research, 11(3), 270-302.

Ohlin, C. (2019). Information and communication technology in a global world. Research in Social Sciences \& Technology, 4(2), 41-57. https://doi.org/10.46303/ressat.04.02.4

Papadakis, S. (2018). Evaluating pre-service teachers' acceptance of mobile devices with regards to their age and gender: A case study in Greece. International Journal of Mobile Learning \& Organization, 12(4), 336-352.

Papadakis, S., \& Kalogiannakis, M. (2017). Mobile educational applications for children: What educators and parents need to know. International Journal of Mobile Learning \& Organization, 11(3), 256-277. 
Poulova, P., Simonova, I., \& Manenova, M. (2015). Which one or another? Comparative analysis of selected LMS. Procedia-Social and Behavioral Sciences, 186, 1302-1308.

Rahmadi, I., Hayati, E., \& Nursyifa, A. (2020). Comparing pre-service civic education teachers' TPACK confidence across course modes. Research in Social Sciences \& Technology, 5(2), 113-133. https://doi.org/10.46303/ressat.05.02.7

Smater, M., \& Zieliński, J. (2015). New approach to automation and robotics vocational education in support of Europe reindustrialization. In R. Szewczyk, C. Zieliński \& M. Kaliczyńska (Eds.), Progress in automation, robotics and measuring techniques. ICA 2015. Advances in intelligent Systems and Computing (pp. 255-264). Springer,

Tadeu, P., Fernandez Batanero, J., \& Tarman, B. (2019). ICT in a global world. Research in Social Sciences \& Technology, 4(2), i-ii. https://doi.org/10.46303/ressat.04.02.ed

Tarman, B. (2016). Innovation and education. Research in Social Sciences \& Technology, 1(1). https://doi.org/10.46303/ressat.01.01.4

Tarman, B. (2017). Editorial: The future of social sciences. Research in Social Sciences \& Technology, 2(2). https://doi.org/10.46303/ressat.02.02.ed

Tømte, C., Enochsson, A. B., Buskqvist, U., \& Kårstein, A. (2015). Educating online student teachers to master professional digital competence: The TPACK-framework goes online. Computers \& Education, 84, 26-35.

Tsirel, S. V. (2017). The economy of the nearest future. Terra Economicus, 15(1), 44-67.

Upadhyay, V. (2015). Can capitalism survive high degree of automation? A comparison with Thomas Piketty's argument. https://ssrn.com/abstract=2558989

Uribe, S. N., \& Vaughan, M. (2017). Facilitating student learning in distance education: A case study on the development and implementation of a multifaceted feedback system. Distance Education, 38(3), 288-301.

Viberg, O., \& Grönlund, A. (2017). Understanding students' learning practices: Challenges for design and integration of mobile technology into distance education. Learning, Media \& Technology, 42(3), 357-377.

Virgillito, M. E. (2017). Rise of the robots: Technology and the threat of a jobless future. Labor History, 58(2), 240-242.

Watson, W. R., Watson, S. L., \& Reigeluth, C. M. (2015). Education 3.0: Breaking the mold with technology. Interactive Learning Environments, 23(3), 332-343.

Wilcox, C. (2015). The role of automation in undergraduate computer science education. In Proceedings of the 46th ACM Technical Symposium on Computer Science Education (pp. 90-95). ACM.

Woofter, S. (2019). Book Review: Building Equity: Policies and Practices to Empower All Learners. American Journal of Qualitative Research, 3(1), 136139. https://doi.org/10.29333/ajqr/5815

\section{Notes on Contributors}

Olga Kalimullina associate professor, PhD in Economics. The Bonch-Bruevich SaintPetersburg State University of Telecommunications, S-Petersburg, Russian Federation. Research interests: digital educational tools, online educational platforms, innovations, knowledge management, innovative development, knowledge model. E-mail: chemireva@mail.ru

Assoc. Prof. Bulent Tarman has more than 25 years of professional experience in the field of education. He earned his Ph.D. degree in Curriculum \& Instruction (social studies education), 
as well as a minor in Comparative and International Education at the Penn State University. He also holds a BA in History from Hacettepe University, Turkey, and an MEd. in social studies education at the University of Missouri, Columbia. His research interests include Social Studies Education, Teacher Education, Innovation in Education, Citizenship and Human Rights Education, Globalizing Education, Curriculum Development, Gender Issues in Education, ICT in Education, and Multiculturalism in Education.

Irina Stepanova, Master Student, ITMO University, St. Petersburg, Russian Federation. Research interests: digital educational tools, usability of MOOC, online educational platforms. Email: iv_trotsenko@mail.ru 